\title{
Finding Big Gay Church: An Academic Congregation Exploring LGBTQ Intersections with Religion, Art, and Education
}

\author{
Mindi Rhoades ${ }^{1}$ \\ The Ohio State University \\ rhoades.89@osu.edu \\ James H. Sanders III \\ The Ohio State University \\ sanders-iii.1@osu.edu
}

\author{
Kimberly Cosier \\ University of Wisconsin-Milwaukee \\ kcosier@uwm.edu \\ Courtnie Wolfgang \\ Virginia Commonwealth University \\ ctownallstar@gmail.com
}

\author{
Melanie G. Davenport \\ Georgia State University \\ meldavenport@gmail.com
}

\begin{abstract}
This article is divided into two parts. The first part provides a detailed description designed to demonstrate and evoke the sense of Big Gay Church, an annual session at the National Art Education Association's convention for seven years. Big Gay Church involves a troupe of art educators using a collaborative participatory and performance-based approach to presenting research on LGBTQ issues in arts, education, visual culture, and society. Combining a generic Protestant church service template, the standard academic conference presentation components, queer theory, and an arts-based approach, Big Gay Church engages and connects art educators with research, knowledge, and one another more meaningfully. The second part presents a theoretical framing and analysis of this ongoing project, including its context, conception, enactment, and reflection. Comments from session attendees (or "parishioners") reinforce the impact of a non-traditional and queer intervention into academia's over-determined spaces, disrupting the appearance of propriety and exclusion of emotional and interpersonal connection. Big Gay Church offers an alternative version of advocacy for social justice through the disruption of academia and its dominant norms and practices.
\end{abstract}

Keywords: LGBTQ; performance-based presentation; queer; LGBTQ allies; religion and homosexuality; academic advocacy

\footnotetext{
${ }^{1}$ Biographical Statement: Big Gay Church refers both to the collective of academics working in the field of Art Education and to their annual conference presentation/ performance delivered as a critique, re-vision, and reterritorializing of religion as open to and inclusive of LGBTQ people and their allies. Entering its seventh year in 2016, Big Gay Church continually aims to disrupt traditional thoughts, theories, scholarship, and conference presentations to enact new possibilities for acceptance, coalitions, and positive cultural change for LGBTQ people and their supporters in alliance with other marginalized and oppressed populations. Big Gay Church accepts members of any, all, and no denominations.
} 


\section{Introduction}

Part I of this manuscript offers a narrative version of Big Gay Church, an annual session at the U.S. National Art Education Association's conference for six years. A group of five to six art educators in higher education form the core performance troupe of Big Gay Church. A dedicated group of congregants attend each year's service/performance religiously, as well as a rotating assembly of enthusiasts, supporters, curious bystanders, and newcomers. Part II of this manuscript focuses more directly on presenting theoretical framing and analysis of major components of Big Gay Church, from context to conception to convention enactment to analysis and reflection. It also contains comments from "congregants" reflecting on their own experiences of Big Gay Church.

\section{Part I: Big Gay Church}

Lady Gaga's song "Born This Way" unexpectedly fills a dim, cavernous, near-empty conference room early Sunday morning on the last day of the U.S. National Art Education Association's annual conference - a typical staid academic setting. The small troupe of inconspicuous academics scheduled to present enter and simultaneously transform themselves. One, Sister Sanders, taking inspiration from San Francisco's Sisters of Perpetual Indulgence, dons a nun habit, and masks his face in clown white, his cornette tenuously gripping his shaved head, his silver beard accented by makeup ostensibly intended for its campy concealment (see Fig. 1).

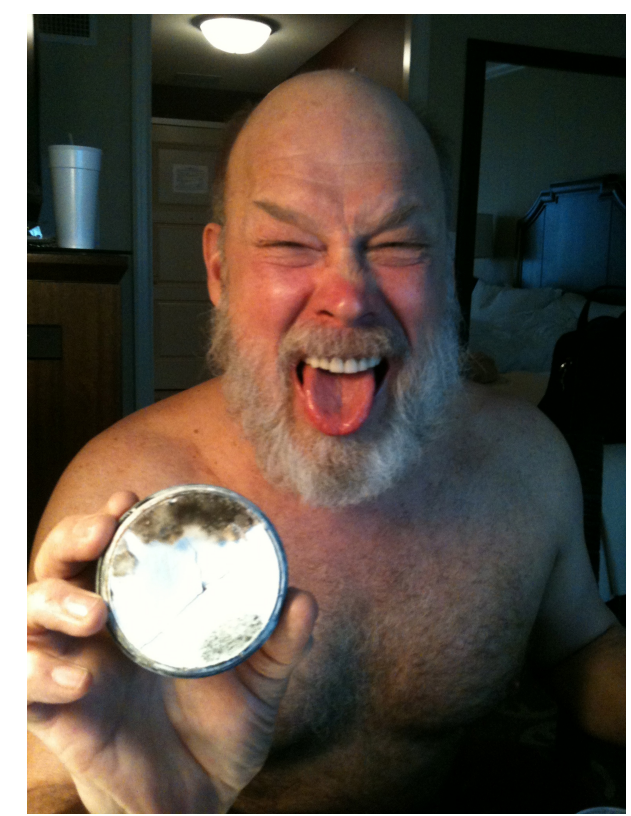

Fig. 1 Becoming Sister Sanders, a nun in the tradition of the Sisters of Perpetual Indulgence

Finding Big Gay Church: An Academic Congregation Exploring LGBTQ Intersections with Religion, Art, 
Another member, Miss Jeanette, channels her childhood evangelical Sunday School teachers in a heavy-knit, shapeless, barely-blue polyester jumper, grey horn-rimmed glasses, a wig possibly stolen from The Golden Girls, and her mostly hidden combat boots (see Fig. 2).

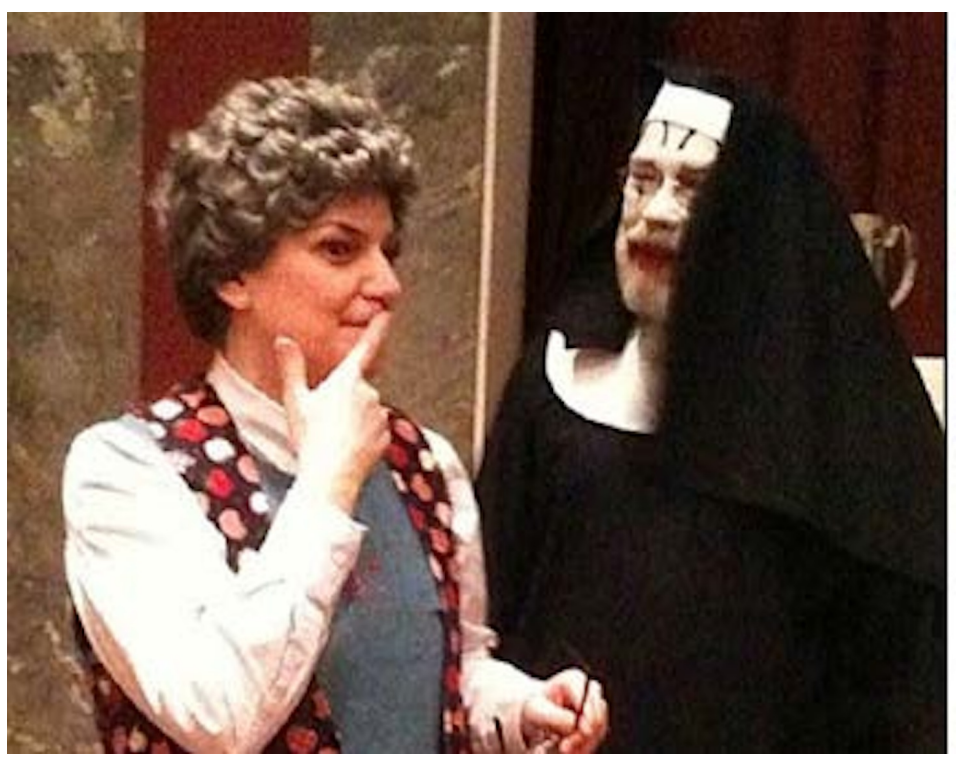

Fig. 2 Miss Jeanette and Sister Sanders share center stage

A third, Brother Love, strums and tunes her ukulele, humming to warm her voice (see Fig. 3).

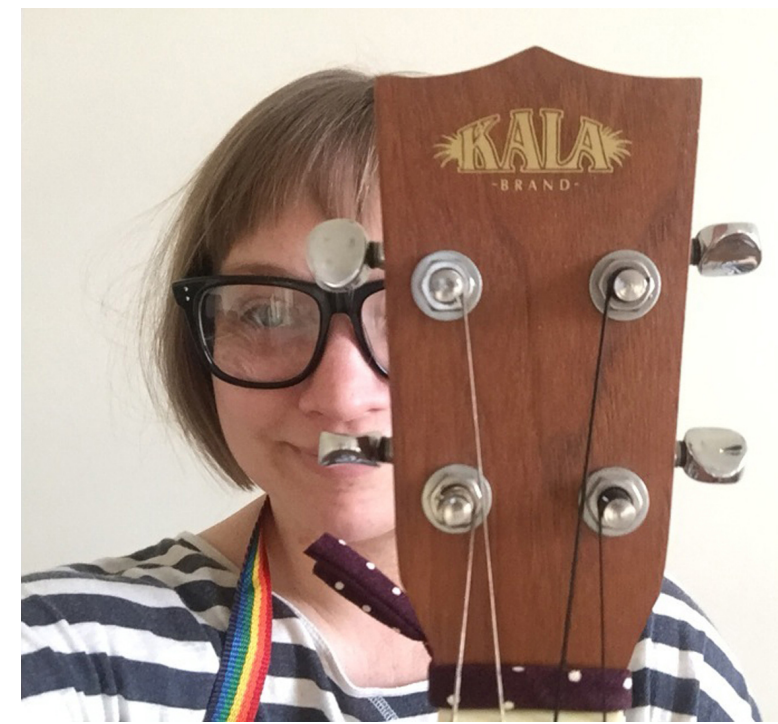

Fig. 3 Brother Love: Our musical minstrel

The Right Reverend dons black robes, places a Bible on the lectern, and prepares for the service and sermon (see Fig. 4).

Art/Research International: A Transdisciplinary Journal/Volume 1, Issue 1 


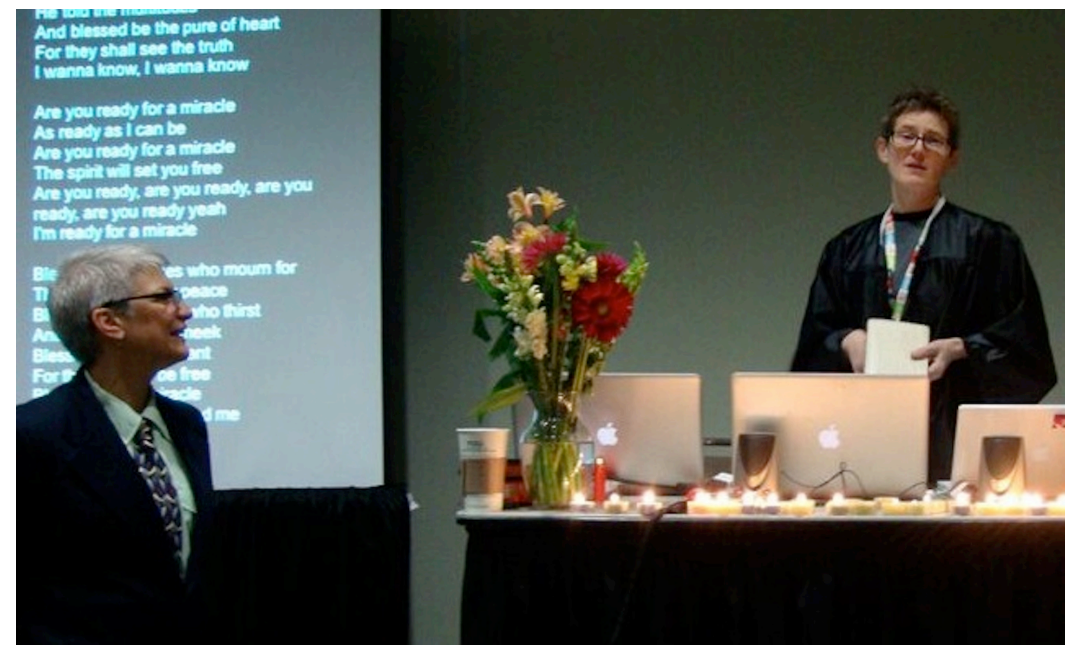

Fig. 4 The Right Reverend preaching from an academic pulpit

Deacon Davenport and assorted assistants become ushers and attendants, welcoming congregants as they enter (see Fig. 5).

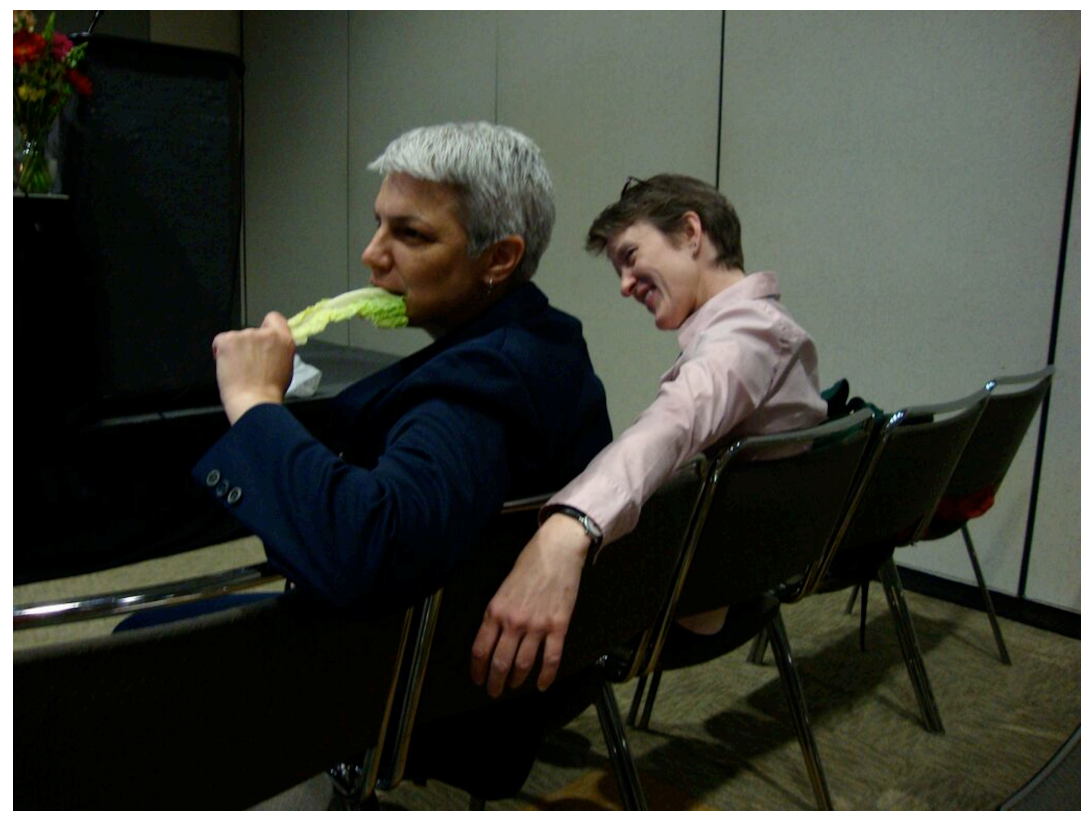

Fig. 5 Deacon Davenport (on right) sits in the congregation

Participant/congregants have been summoned through playful flyers, postcards, invitations, and other enticements. They are greeted with banners, flags, streamers, programs, and trinkets, such as kazoos, at the door (see Fig. 6). Big Gay Church begins. 


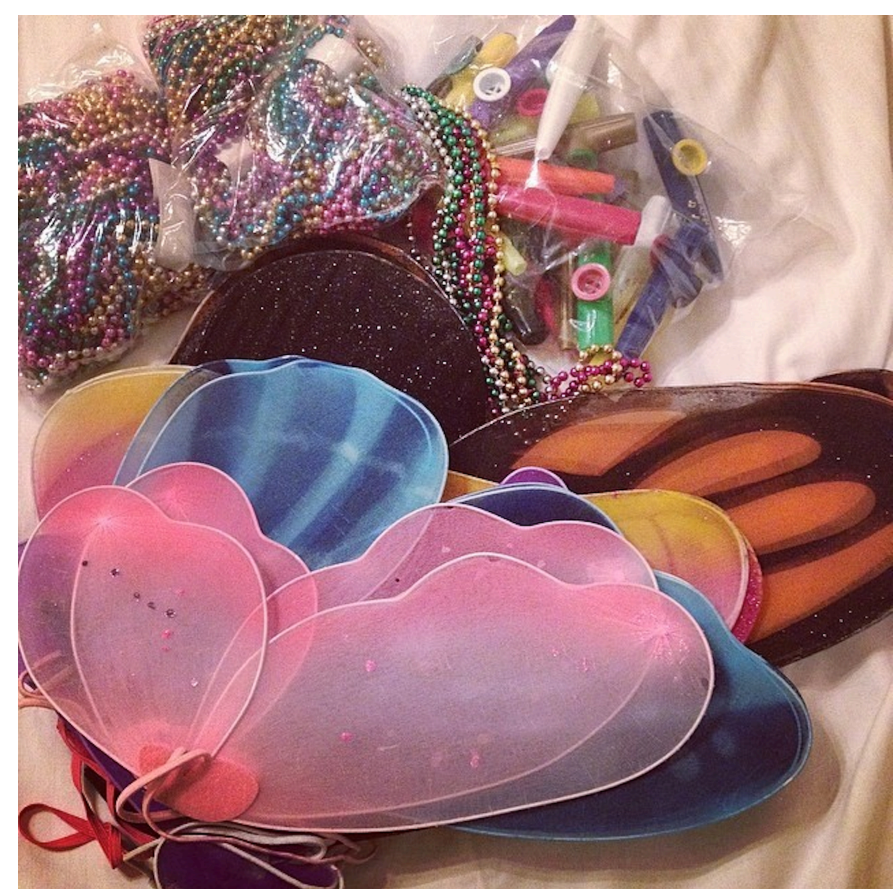

Fig. 6 Big Gay Church supplies (wings, kazoos, shiny bead necklaces)

\section{The Big Gay Church service ${ }^{2}$}

As people find seats and the music begins to fade, the Right Reverend steps to the podium to formally begin the service. She starts with the reading of Biblical scripture and an opening prayer.

\section{Scripture reading}

Love is patient, love is kind. It does not envy, it does not boast, it is not proud. It is not rude, it is not self-seeking, it is not easily angered; it keeps no record of wrongs. Love does not delight in evil but rejoices with the truth. It always protects, always trusts, always hopes, always perseveres. Love never fails. But where there are prophecies, they will cease; where there are tongues, they will be stilled; where there is knowledge, it will pass away.

And these three remain: faith, hope and love. But the greatest of these is love.

\footnotetext{
${ }^{2}$ This section follows a standard format for many weekly Christian church services in the U.S. where congregants each receive a copy of the agenda to follow along throughout the service.
} 


\section{Opening prayer}

\section{The higher principle of love}

Grant that the resources that we have will be used to do good - the great resources of education, the resources of wealth - and that we will be able to move into this new world, a world in which people will live together lovingly. A world in which people no longer take necessities from the masses to give luxuries to the classes. A world in which we throw down the sword and live by the higher principle of love. At this time we shall be able to emerge from the bleak and desolate midnight of man's inhumanity to man into the bright and glittering daylight of freedom and justice. There will be a time we will be able to stand before the universe and celebrate this love with joy.

(King "The Birth of a New Age" 346)

\section{Welcome}

The Reverend Rhoades then encourages the congregants to stand and take a moment to greet and welcome those nearby. As people rise, the noise level and warmth of the room rise also. People smile, shake hands, say hello, some even embrace. After a few moments, Brother Love begins strumming the ukulele, which signals the crowd to sit.

\section{Hymn}

Brother Love motions to the lyrics of a song projected behind her, inviting everyone to sing along as she enthusiastically launches into the hymn. Many audience members find it familiar and join immediately. Others listen for a moment, get the tune and rhythm, and quickly join, too. Again the room swells with choral sound and communal connection.

\section{All God's children got a place in the choir (chorus)}

All God's creatures got a place in the choir

Some sing low

Some sing higher

Some sing out on the telephone wire

Some clap their hands or paws or anything they've got now!

(Staines)

We sing several verses, each louder than before. As the hymn ends, Brother Love softens her song, strumming fading, ceding center stage to Sister Sanders.

Finding Big Gay Church: An Academic Congregation Exploring LGBTQ Intersections with Religion, Art, 


\section{A (queer) reading from the Old Testament (for art + art education)}

Sister Sanders, holding tightly to her still slippery cornette, signals for the PowerPoint projection that accompanies her current segment of the service. The Sister begins by sharing video clips from The Sisters of Perpetual Indulgence, a legendary San Francisco drag troupe. In the video Sister Merry Peter declares,

Why is everyone so afraid of humor or laughter? This [performance] is not mocking someone but it's [aimed at] opening you up. It's the idea of the holy fool-that ancient idea that there's someone who stands looking completely absurd and gives you permission to say things that are completely true and honest without misperception, covering, avoidance or hypocrisy. (Sisters of Perpetual Indulgence)

Sister Reign of Terror leads a recitation of the pledge of the Sisters of Indulgence:

I, Sister [insert name here], as a member of the Order of the Sisters of Perpetual Indulgence, dedicate myself to public service, social activism, and spiritual enlightenment. (Sisters of Perpetual Indulgence)

Sister Sanders, after reinforcing her spiritual and ideological connection with these kindred sisters, delivers the most traditional academic component of this session - a PowerPoint presentation and lecture. However, Sister Sanders does this cross-dressed as a nun caught in an awkward, constant, and doomed struggle to maintain her headgear against the laws of physics and friction. Slideby-slide, our Sister insistently recognizes queer artists and their contributions to religious art and cultural production; queers serving the Church, often closeted, as clergy and congregants; and queer theory as a valid framework for critically exploring the intersections of (visual) culture, religion, art, art history, and art education. Sister Sanders' slides and lecture also present historically successful queer acts of outrage as arts-based methods of political and social critique that create interventions, such as the Stonewall Riot (1968), the carnivalesque San Francisco Cockettes (late 1960s/early 1970s), the AIDS Coalition to Unleash Power (ACT-UP) (early 1990s), Pride Parades, and significant queer arts and pop culture representations (see Fig. 7). 


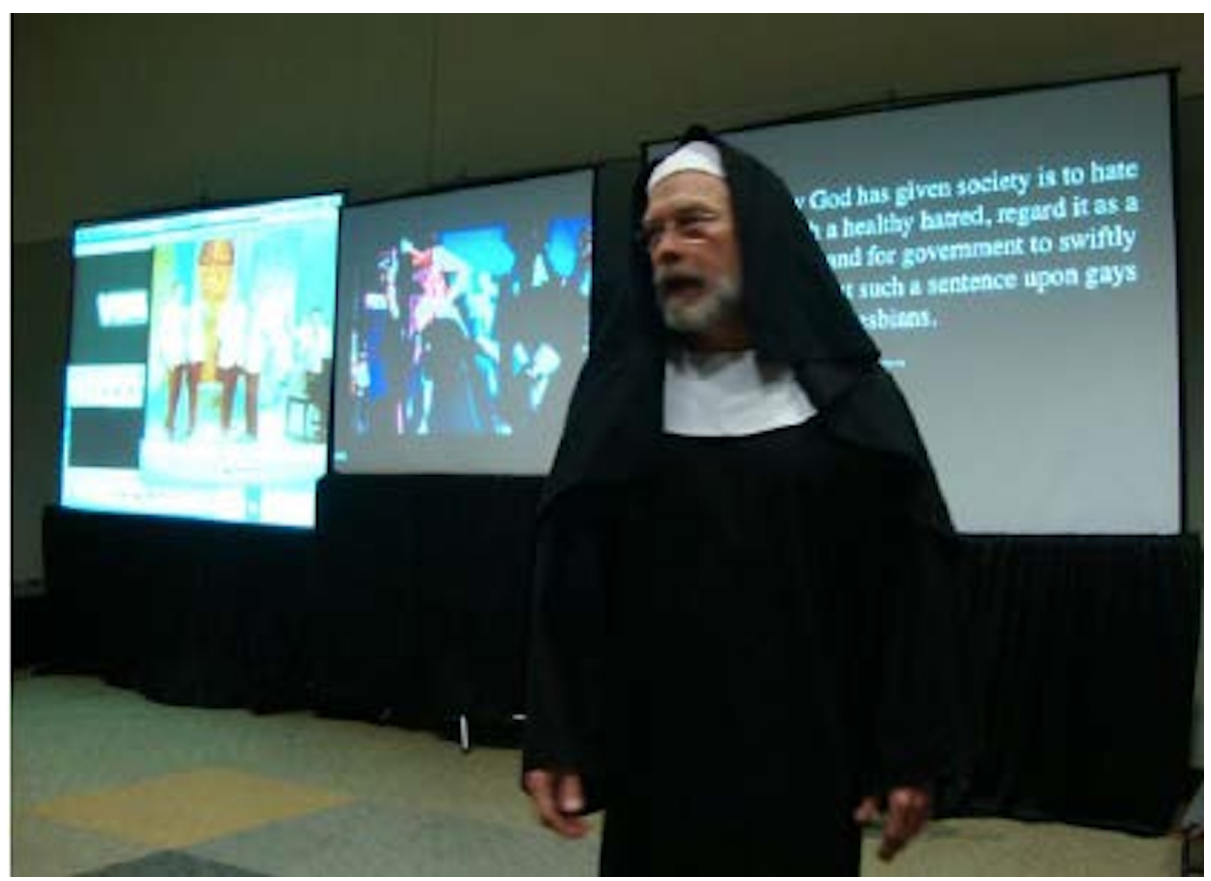

Fig. 7 Sister Sanders showing slides

Sister Sanders ends, as always, suggesting ways to disrupt dominant oppressive discourses, using queer theory in performative, productive, and pragmatic ways (Sanders). The campy drag theme continues into the next segment of the service.

\section{Children's Sunday school lesson with Miss Jeanette}

Miss Jeanette shuffles onto stage to a cascade of laughter from the congregation, adjusting her grandma glasses, smoothing the bluish dress, and fluffing her white-gray wig. She begins her lesson with a traditional Sunday School teacher greeting: "Now boys and girls, today we are going to learn about special people, kind of like angels who walk among us. These people help support awareness and acceptance for our queer brothers and sisters." The first "gay angel" Miss Jeanette anoints is Rachel Maddow, for her openly queer presence in mainstream media and her work around LGBTQ people, issues, and rights. After Miss Jeanette discusses Rachel Maddow's qualifications as a "gay angel," she distributes original Rachel Maddow gay angel trading cards to the congregation ${ }^{3}$.

\section{Testimony}

\footnotetext{
${ }^{3}$ Subsequent years' cards have included Van Clyburn, Vito Russo, Elizabeth Taylor, and others.

Finding Big Gay Church: An Academic Congregation Exploring LGBTQ Intersections with Religion, Art, 
As Miss Jeanette's gay angel cards circulate, Deacon Davenport assumes leadership for the Testimonial section of the service (see Fig. 8).

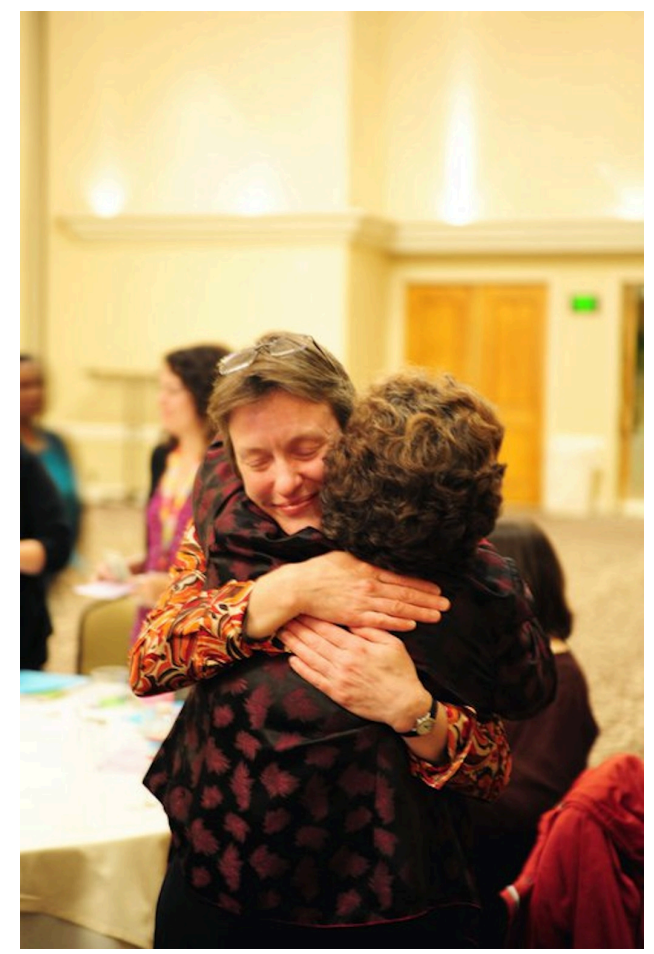

Fig. 8 Deacon Davenport spreads the love

Deacon Davenport opens this section by sharing a video testimonial interview with a lesbian who grew up and participated wholeheartedly in her family's evangelical church congregation. After she came out, she was explicitly condemned and summarily excommunicated. Her story is a familiar one, or at least resonates with a familiar fear, for many LGBTQ folks in similar religious contexts.

Deacon Davenport then invites other congregants to bear witness or share their own stories. One congregant describes belonging to a congregation very open and welcoming toward LGBTQ people and how that impacted her decision to join. A gay man talks about working in his Catholic school in a constant state of fear of being exposed and fired. Another notes the need for progressive and liberal Christians to counter the constant conservative Christian condemnations of homosexuality, to make sure intolerant people cannot casually claim the mantle of "Christian," and its presumed moral heft, while expressing such hate. As the testimonials end, the Right Reverend moves to the lectern to begin the sermon. 


\section{Sermon}

The Right Reverend wears a shiny black robe and carries her childhood Bible; her mild-mannered preaching betraying multi-layered subversion. Her Southern Christian upbringing's conflict with her homosexuality and gender nonconformity catalyzed a personal crisis and rejection of organized religion. Ordained online, she circumvented the patriarchal, heterosexist system, avoiding years of seminary and official denominational affiliation. As a female minister, she disrupts fundamentalist religions' misogynistic gender hierarchy; as a fairly androgynous lesbian, she breaks traditional gender and sexuality church boundaries too. She moves easily between Bible verses, religious texts, and popular culture. She reads, asking questions, seeking multiple possibilities, crafting productive tensions, and opening sacred and scholarly spaces for inclusion and love:

As art educators grappling with issues of representation, interpretation, translation, and identity, this discrepancy between the thing itself and multiple contradictory or complicated interpretations and enactments of it may sound a familiar chord. Why, when we look for diverse interpretations and associations as a form of richness, in art-making, art criticism, and writing as and about art, do we continue to insist on singular interpretations of Biblical texts and a pure, unadulterated holy truth? Why would everyone interpret a text the same exact way? Don't we see the impossibility of complete consensus? Don't we recognize, when returning to texts, religious or otherwise, that they mean different things to us in each encounter or remembrance or enactment?

Reverend Dr. King believed it is people like us who can make a difference. $\mathrm{He}$ insisted, "The question is not whether we will be extremists, but what kind of extremists we will be...The nation and the world are in dire need of creative extremists." He adds, "Almost always, the creative dedicated minority has made the world better" (King "Letter from a Birmingham Jail" para. 24). Not only can we do this, he believes we should do this. This stands in such direct contradiction to many of the messages we receive socially and culturally about being LGBTQ, particularly as people continue to vote for our rights as complete citizens.

(Rhoades "iDo" sermon excerpts)

As congregants contemplate the messages presented, our Deacon Davenport and volunteer ushers prepare to pass the Big Gay Church plates.

\section{Offering}

Finding Big Gay Church: An Academic Congregation Exploring LGBTQ Intersections with Religion, Art, and Education 
The Big Gay Church offering is queer. Different. Instead of congregants offering us, Big Gay Church, some kind of gift or compensation, Big Gay Church distributes offerings to them. These range from small handcrafted artworks, to Saint Cards, to paired sets of officially blessed and sanctioned "Loved" and "Forgiven" cards, to paper fans with outlined Sister Sanders for coloring (see Figs. 9 and 10).

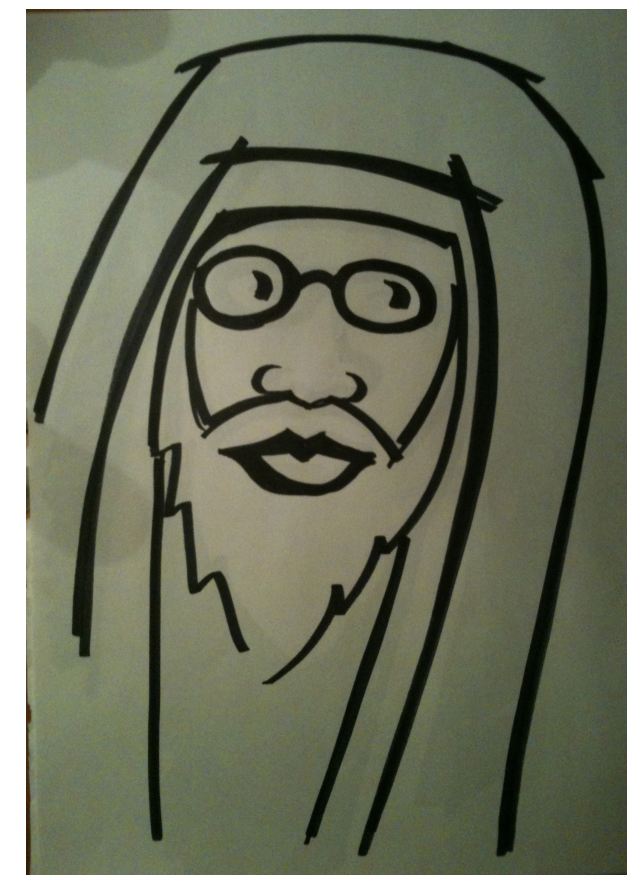

Fig. 9 Sister Sanders fan line drawing (blank)

\section{Open prayer and meditation: Holding up to the light}

Miss Jeanette returns and opens our communal call to prayer, inviting the congregation to name people they want us collectively to "hold up to the light." Sister Sanders starts, requesting positive thoughts for a brother-in-law after recent transplant surgery. Other congregants follow, mentioning mostly family members and some friends for congregants' consideration. Finally, a prominent art education scholar asks us to do this for another in the room - her best friend of many years who is struggling with an aneurysm requiring brain surgery. She voices a silent shared concern, a collective fear we try to overcome with collective tears, try to wash away with love. The communal connectedness of caring is explicit and electric. 


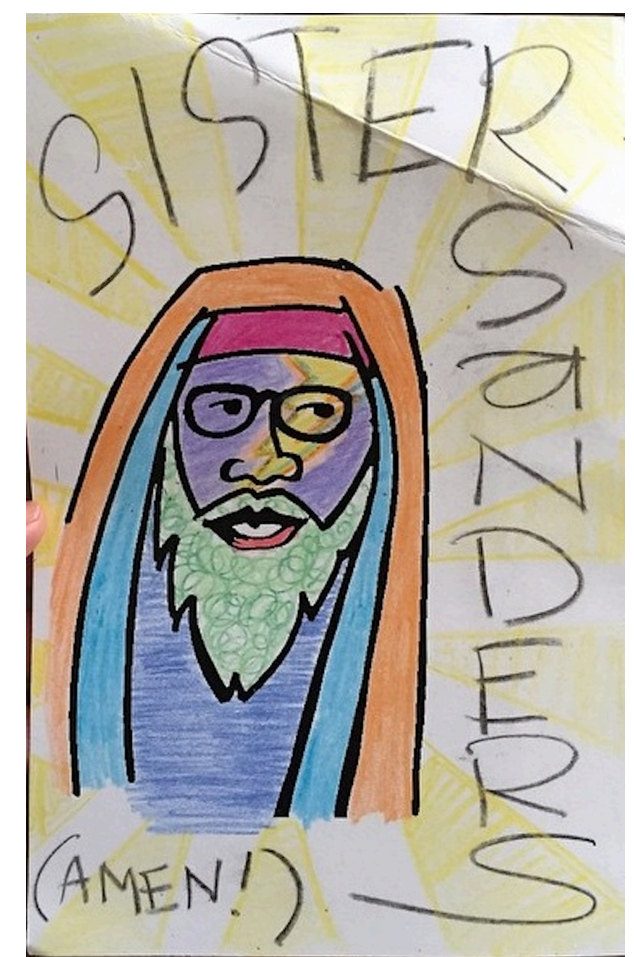

Fig. 10 Sister Sanders fan (hand-colored)

\section{Communion}

From prayer and meditation, we progress to official communion, the essential component and intent of Big Gay Church. During the first service ushers opened leftover bottles of wine, distributed plastic cups, and offered assorted baked goods with club music soft in the background. Congregants ate, drank, and chatted. Another year, communion involved a Pancake Supper, with troupe members shifting into line cooks, serving up warm pancakes and syrup (see Fig. 11).

At another service, aligned with the conference theme "Sparkle and Shine," communion involved creating colorful paper hats congregants then wore for a surprise Pride parade, led by pole puppets, winding through the convention center and the vendors' area, then culminating in a wedding vow renewal ceremony outside overlooking San Diego Bay (see Fig. 12).

Brother Love follows the communion by building on our sense of connection, leading congregants in a final hymn of possibility, emphasizing art education's strength: imagination. 


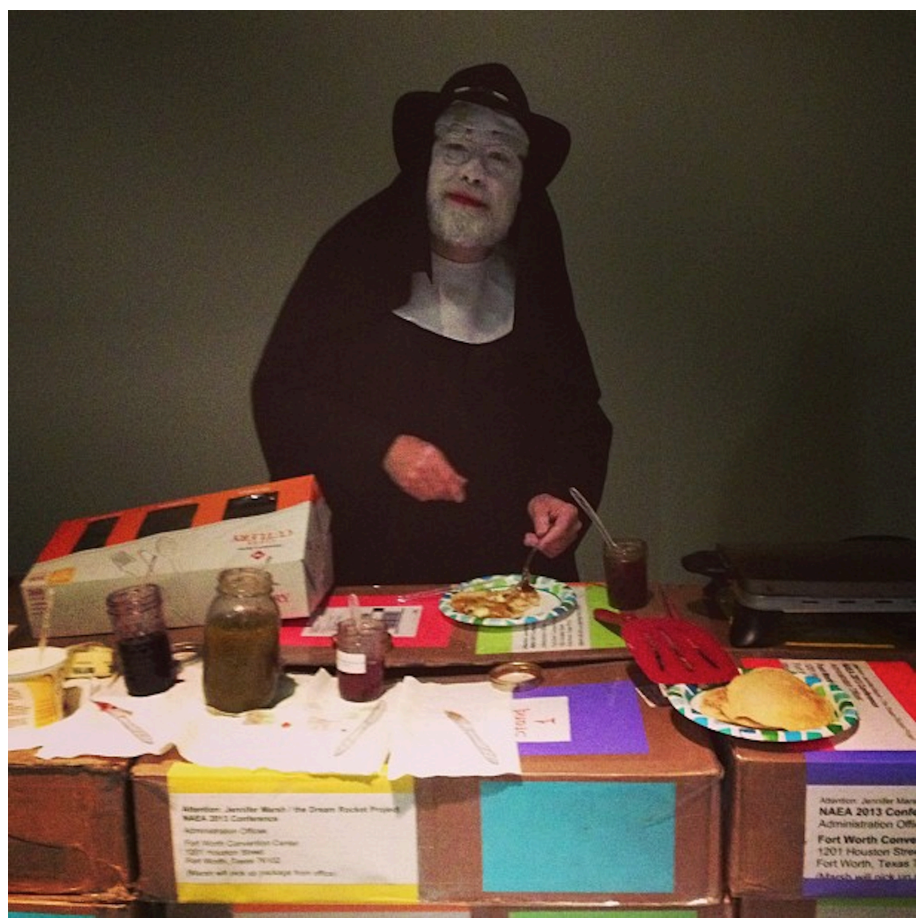

Fig. 11 Sister Sanders serving pancakes to parishioners

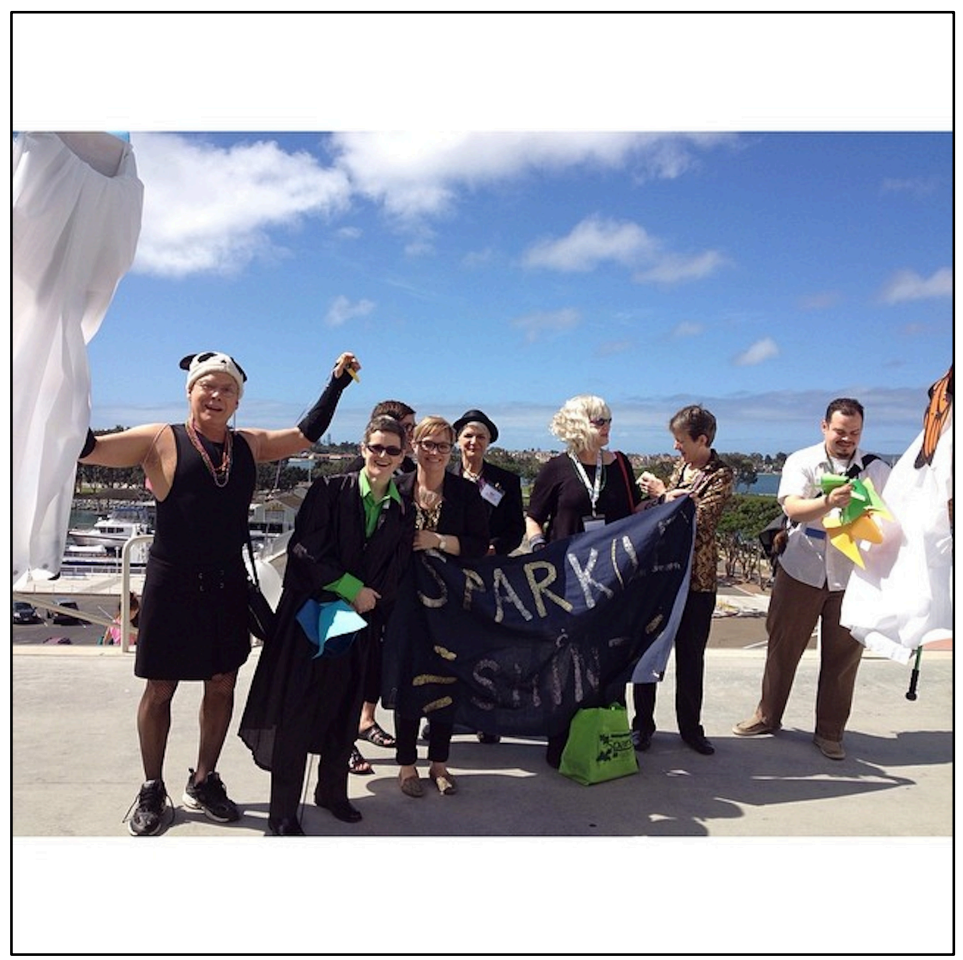

Fig. 12 Big Gay Church group photo post Spark(le) + Shine service in San Diego 
Closing hymn

For the closing hymn, we play a version of John Lennon's "Imagine" with the words projected for people to sing along with the song. We include Lady Gaga's added verse in support of marriage equality because we share her belief that real democracy - real equality - does mean letting people be who they are and love who they love.

\section{Benediction}

After imbibing the soft quietness and stillness that follows, The Right Reverend returns to the podium with final thoughts for the congregation: Like Lady Gaga, John Lennon, Jesus, and many, many others urge, we must learn to accept and love ourselves and each other. Listen to their repetition of the three most important Biblical beliefs: faith, hope, and love. Remember the longstanding ability of the LGBTQ community to dance in the face of oppression, to sing over shouts of condemnation, to love regardless. Love each other and know that we love you.

Amen.

As we bring closure to the service, we invite the congregation to continue their fellowship in our Big Gay Sanctuary until the next session. The sanctuary transforms back into the nondescript, intentionally standardized traditional conference room. Our pews fade into seats locked in lines, our wine replaced by sweaty silver pitchers and half glasses for water. Our altar, a stage again. Our alter-egos disappear, pulled off and packed away in suitcases for travel home with the homos, to be stored and ready for our next service. We hug, shoving final items into our bags, saying goodbyes, speaking of later meetings, of future plans. We walk out the church doors and into the convention center halls, out of the temple and into the marketplace.

\section{Part II: Conservative Christianity, Education, Arts, + Activism}

\section{American Christianity and queerness}

Aren't you beginning to at least get a glimpse of why God commands governments to put homosexuals to death (Lev. 20:13)? Or are you still foolishly closing your eyes, ears and hearts to the truth? (Lee) ${ }^{4}$

\footnotetext{
${ }^{4}$ Lee runs an organization called The Society for the Practical Establishment and Perpetuation of the Ten Commandments. It primarily consists of a website (tencommandments.org) of hate-filled rants against heathens, homosexuals, abortionists, democracy, America, and science. They advocate for replacing the U.S. Constitution with the Ten Commandments.
}

Finding Big Gay Church: An Academic Congregation Exploring LGBTQ Intersections with Religion, Art, and Education 
We begin this section with the context for the development of Big Gay Church, starting with the struggle for LGBT/Queer rights in relationship to efforts by conservative Christians to curtail these rights and condemn "queers." Great strides are being made in the United States with regard to certain aspects of queer life. As the tencommandments.org quotation above suggests, however, a backlash in the name of God is also afoot. There is much to be learned through the study of this contradiction. Although there are many controversies and problems with the Bible and its translation across languages over millennia and around the globe, it remains a primary sacred text globally. Therefore, even though the concept of homosexuality did not exist in biblical times (Foucault), interpretations of what the Bible ostensibly says greatly influence the treatment of LGBTQ people in Judeo-Christian societies. Troublingly, these interpretations are based not in divine dictate, as so many believe to be true, but insinuated in Biblical translations during Europe's cultural shift against homosexuality. Consequently, early European colonists to the U.S. imported this punitive, condemnatory attitude toward queers.

Many U.S. fundamentalist and conservative Christian churches continue to adhere to anti-homosexual beliefs and practices. This contemporary crusade began in earnest in the late 1970s as conservative Christians entered the political arena with a vengeance. In 1978, religious leaders unsuccessfully supported California's Proposition 6 to legalize discrimination and force the firing of all homosexual teachers (Wolff and Himes)

After founding notoriously conservative Liberty University in 1971, the famous Southern Baptist televangelist Jerry Falwell co-founded the Moral Majority in 1979 as a political action organization aimed at consolidating the political and cultural power of conservative Christian congregations, organizations, and individuals. Falwell was known for blaming "gays" for many crises and disasters, including calling HIVIAIDS God's punishment for gays and blaming homosexuals and their allies and supporters for 9/11 (Press). The 1986 Helms Amendment, named for rabid homophobe Senator Jesse Helms of North Carolina, banned federal taxes for AIDS research and prevention efforts in schools. The Moral Majority supported 1986's California Proposition 64 to quarantine HIV-positive gay men as a threat to society (Wolff and Himes). Focus on the Family's Dr. James Dobson supported the Boy Scouts' ban on gay scout leaders, calling gay men dangerous pedophiles (Wolff and Himes). In 2008, California's Proposition 8 to prevent (LGBTQ) marriage equality was "primarily funded by Mormon, Catholic, and Evangelical churches" (Wolff and Himes; see

\footnotetext{
${ }^{5}$ Throughout this section, we will use the abbreviated term "LGBTQ" (for lesbian, gay, bisexual, transgender, and queer/questioning) to be inclusive of all forms of queerness.
} 
also 8: The Mormon Proposition). Big Gay Church asserts a different idea of God and faith, one that sees hateful acts against the moral minority as a grave $\sin$.

Catholicism's anti-homosexual doctrine was formally codified in a 1975 official pronouncement that "incurable homosexuals should be treated kindly" but "homosexual behavior can never be justified" (qtd. in Lynch 387-388), what became colloquially "love the sinner, hate the sin" (Callaghan 85). Cardinal Ratzinger (who later became Pope Benedict XVI) shifted this tone, condemning homosexuals as inherently evil, disordered people who provoke and deserve punishment with their wicked ways (Buchanan et al.; Callaghan), advocating discrimination against allowing homosexuals as foster/adoptive parents, teachers, coaches, or soldiers. In 2002, U.S. Vatican spokesperson Joaquin Navarro-Vails attempted to blame gay priests for the exploding clerical child sexual abuse scandal (Lynch).

Currently, the Catholic Church struggles to balance historically nurtured attitudes of disgust and condemnation with contemporary impulses toward respect, sensitivity, and love (Candreva). Pope Francis, who was called a "global spiritual rockstar" in the Huffington Post, rocked many with his simple yet powerful question "If someone is gay and he searches for the Lord and has good will, who am I to judge?" (Donadio). Even before this groundbreaking query, some American bishops sought to help parents/families of LGBTQ people negotiate the church directive to condemn homosexual behavior with the Biblical directive to love your children as gifts from God. Other more conservative bishops and Vatican officials countered, insisting Christian morality justifies religious condemnation and legalized discrimination against homosexuals (Lynch).

Many U.S. protestant denominations have followed a similar trajectory. Some U.S. denominations and congregations have made progress toward LGBTQ tolerance; others continue their crusade against queer people. Conservative Christianity still retains great cultural, political, and legal influence in the U.S., perhaps most visibly in what H. L. Mencken termed the "Bible Belt" of Southern States (Mencken). Several fundamentalist Christian denominations with large congregations and outsized influence - including Southern Baptists, Pentecostals, and newer denominations like Jehovah's Witnesses and Mormons, maintain very hardline positions against homosexuals, lobbying for continued legal oppression and penalization (Sharlet). In Big Gay Church, we seek to out contradictions and hypocrisy and expose them, without wholesale condemnation of other churches. We understand that faith is a complex, fluid, and mysterious thing. One might even call it queer (Sanders; Zacko-Smith and Smith).

Finding Big Gay Church: An Academic Congregation Exploring LGBTQ Intersections with Religion, Art, 


\section{Becoming Big Gay Church}

Because [homosexuality] is such a great curse to humanity, the God who created humans says put homosexuals to death (Leviticus 20:13)! They ought not to be allowed to live! (Lee)

Big Gay Church operates against this complicated, conflicted backdrop of religions' relationships with queer people. More specifically, Big Gay Church's core members have extensive experience growing up and living in conservative and religious cities, small towns, and communities across the Bible Belt. As queer youth, and now as adults, we are sensitive to the power of Christianinfluenced discourses around sexuality, gender identity, and morality in family and civic life.

Most Americans (including we queers) grew up in families subscribing to some religious faith (LeVay and Nonas; Schuck and Liddle). In many of these situations, queers face a "pervasive and potentially annihilating Christian discourse" (Schuck and Liddle 310) that precipitates near-constant fear of being outcast, harassed, or even physically injured. These fears can create or exacerbate self-loathing and general low self-esteem (Schwartz). Many queers express a desperate desire for congregational acceptance, to "go to church sometimes, and not be afraid of just being told what a horrible person you are" (Barton 466). It is an understanding of this desire that led us to create Big Gay Church. It is this situation that leads some people to our sessions, like those who find themselves closeted and working in religious schools or even deeply religious communities. They come to Big Gay Church to confess their circumstances, to seek solace, to find fellowship.

Some queers from conservative faiths undertake a futile struggle to overcome or cure their non-normative sexual identity, and when this fails, they believe they have forfeited their "faith, God, their church, or their fellow believers" (Ganzevoort, van der Laan, and Olsman 218). In some cases, queers (and their congregations) believe that if they are unable to change their sexuality, accepting it comes at "the price of abandoning God," that "apostasy then may not be a choice, but an unavoidable conclusion" (Ganzevoort, van der Laan, and Olsman 220). In Big Gay Church services we confront conservative Christianity's condemnation of queers and examine how their prevalence and power can create oppressive living conditions for queer people, undergirding homophobic laws, tolerating discrimination and harassment, and even promoting violence (Brooke; Cianciatto and Cahill; Dennis; Williams). We have shed light on the ways some conservative Christian congregations, pastoral leaders, and parents or guardians literally force queer minors into "conversion therapies" aimed at fixing a person's sexuality that more likely "result in psychological harm and are 
not effective" (Wolff and Himes 443). Our congregants, many of whom are not queer themselves, learn of these damaging therapies as well as the hopeful message that California and New Jersey have outlawed the medically-debunked practice and several others are following suit.

It is against the backdrop of this lingering conservative, religion-based persecution that members of the Big Gay Church troupe coalesced, bonding over mutual firsthand experiences in conservative churches and so-called "Godfearing" communities. We shared ways church still impacted our lives and how it shaped us as artists, educators, citizens, and activists. For us, every discussion of injustice against queers eventually conjured the church, implicating it as the prime source of friction around sexuality - in society and in education. We acknowledge the chilling impact this has on teachers, students, and schools.

We considered ways this chill creeps up in higher education - impacting our research, publication options, teaching, professional standing, job options, and tenure. While good Christian grandmothers from the Freewill Baptist Church have not prowled the halls of academe, for some of us pervasive conservative values dictate our marginalization and contribute to a resistance to queer ideas in our scholarship and teaching.

Each of us experienced some shock in realizing that the field of art education, which we had presumed to be more liberal, was every bit as apt to present challenges, from minor restrictions and self-censoring, to penalizing unauthorized perspectives in higher education. Collectively, we wondered what our lives - and those of our students, colleagues, and community members, would be like if religion didn't demonize queer people. What if instead of rejecting all things queer, churches embraced and celebrated queers in all our complicated, contradictory, and convoluted glory? What if we created an alternative universe where queer people ran a church in which everyone was welcome and loved? We longed for a church that was fun and welcomed camp. Big Gay Church was born (see Fig. 13).

We began considering ways to productively and queerly explore these possibilities by asking how we could queer church [as a mis-service]? We wanted to do more than merely emulate and discuss gay-friendly and welcoming examples, such as the Metropolitan Community Church, Unitarian Universalists, and more tolerant congregations within larger denominations like the Dignity Roman Catholic congregations or the Baptist Peace Fellowship. We sought to create a religious community that explicitly embraces all sexualities, celebrates and theorizes transgression of gender binaries, and perhaps even embraces our own contradictions. As an example, in latter years, Sister Sanders complicated her character, evolving from a campy drag nun to Hermana Harry, a more gender-disruptive and ambiguously fluid persona (see Fig. 14). 


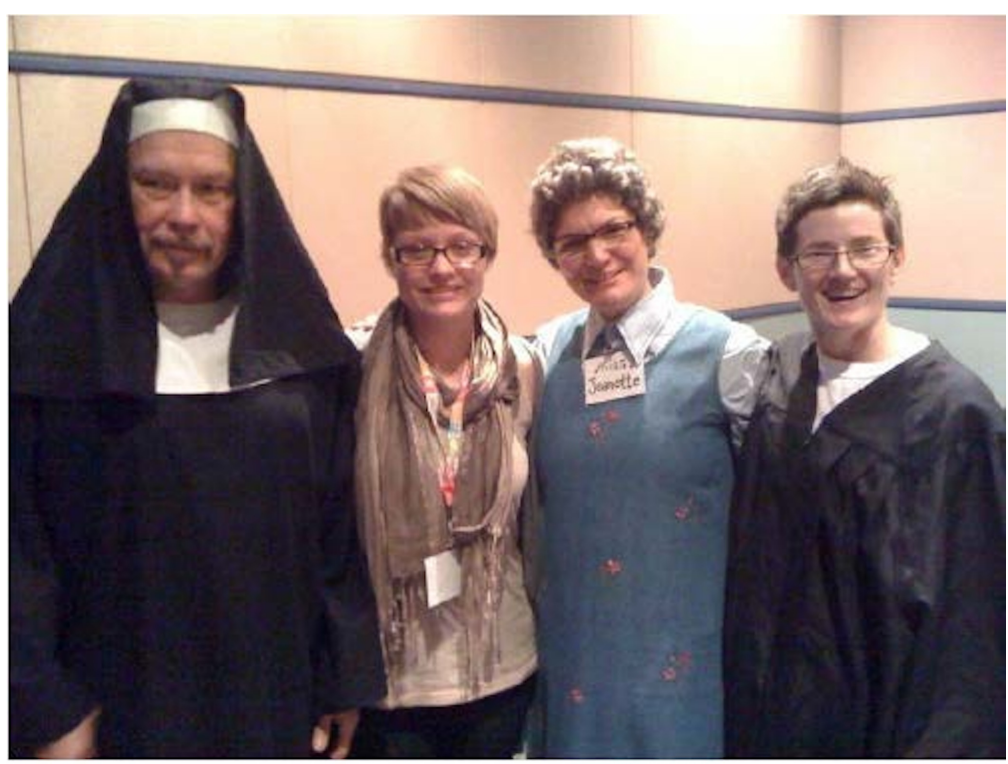

Fig. 13 Sister Sanders, Brother Love, Miss Jeanette, and the Right Reverend

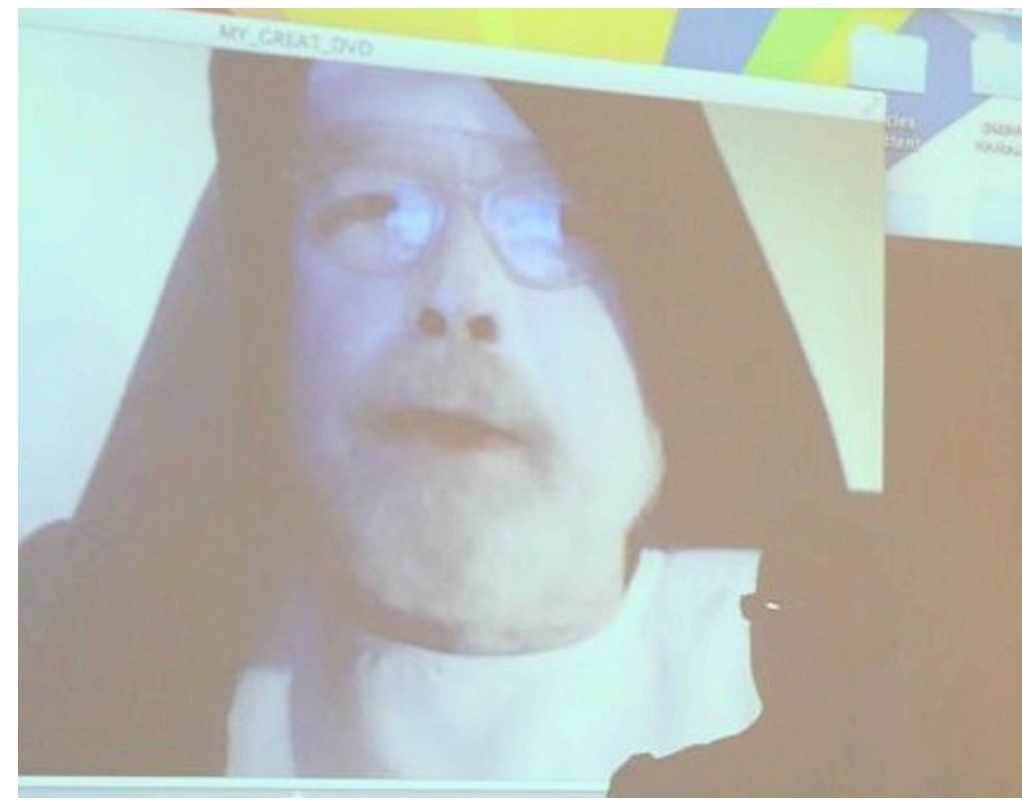

Fig. 14 Hermana Harry appearing as a digital ghost from a fictional place/time

We wanted to disrupt the normative constraints around LGBTQ issues in art education by disrupting the conventional staid expectations for the standard conference presentations in terms of form and content. Instead of a symposium, we imagined a service; instead of a cathedral, we imagined transforming a conference room; instead of condemning, we imagined communing. We proposed inserting queers into religion to create a "gay church," inserting these queers with their "gay church" into academic contexts, and using this disruption 
to coalesce as a group, then question, challenge, and hopefully provoke change in participants' thinking, teaching, and daily lives.

\section{Art + activism $=$ Artivism}

At no point in American history have there been proper laws against the existence of gays. If any society foolishly allows them to live, they will gradually endeavor to shape society in such a fashion to legitimize their evil and extend to themselves the same rights that society should only extend to worthy citizens. If allowed to live, they will seek to be educated. If allowed to be educated, they will seek employment in key fields of society and positions of public trust so as to enable them to promote their evil and nasty agenda. They will become doctors, psychologists, scientists, senators, congressmen, judges, etc. (Lee)

Our troupe is currently combining and deploying what youth development scholars Ginwright and Cammarota call critical civic praxis and Sandoval and Latorre call artivism. Such strategies provide productive ways for us to analyze, share, and apply arts-based educational research and pedagogies. For Ginwright, Cammarota, and Noguera critical civic praxis prompts marginalized populations to collective action. Critical civic praxis combines: recognizing current and potential political activism; awareness of socio-cultural inequities; a strong sense of community; collective action; transformation of learners to educators; and opportunities to imagine, design, and implement creative social justiceoriented responses/interventions, into a strong roadmap for guiding collaborative learning and activist work (Ginwright, Cammarota and Noguera). Big Gay Church manifested, as we noted, the injustices perpetuated and the lingering homophobic overtones in dominant cultural discourses that continued to marginalize and oppress queers, and decided to try to do something about this. Beginning with a small group, we envisioned a collective action within the constraints of our academic field that could allow us to educate others using creative arts-based methods for cultivating a more equitable educational and cultural environment.

Sandoval and Latorre's concept of artivism moves critical civic praxis into the world of arts and visual culture. Sandoval and Latorre define artivism as a hybrid of artistic production and activism that harnesses their potential symbiosis for transformational purposes. Artivism offers what California Chicana artist, and out lesbian, Judy Baca stresses are "unprecedented means" for marginalized populations - youth, minorities, to represent themselves and tell their own stories outside of mainstream and adult control (Sandoval and Latorre 86). Like critical civic praxis, artivism enacts pedagogy that recognizes the "persisting exclusions" of the arts and visual culture, yet builds on their "liberatory potential" and collective cultural capital, emphasizing ways "creativity can be channeled, augmented, and empowered" through "real-world and on-the-ground" arts-based

Finding Big Gay Church: An Academic Congregation Exploring LGBTQ Intersections with Religion, Art, 
strategies (Sandoval and Latorre 84). In a sense, artivism is creative critical civic praxis (Rhoades "LGBTQ youth + video artivism").

For Big Gay Church, critical civic praxis allows us to interrogate oppressive stereotypical institutional and interpersonal power dynamics. By proposing Big Gay Church as a formal conference session through authorized channels, we are challenging and circumventing traditional institutional and disciplinary barriers to conversations and progress related to queer issues and concerns in (art) education. We are attempting to work within the professional organization in our field to disrupt the discriminatory dominant discourses and silences we observe and encounter. We are attempting to do this through the use of arts-based interactive methods. Artivism provides a framework for us to present critical issues more creatively, through works of the imagination, to open negative aspects of dominant queer cultural discourses to possibilities of change, and to help others transform from marginalized victims into agents (Ginwright and Cammarota; Sandoval and Latorre).

With Big Gay Church, we take an artivist approach on several fronts simultaneously. Since schools and education often derail non-heterosexual and/or gender queer identities and discourses, we make space for queer people and voices in our professional organization for considering, and experiencing, alternative perspectives, figuratively by being out and visible under the institutional approval of the national association; literally by providing a time during each service for congregants to speak - to tell their stories or just announce their existence as queers (and/or allies). The subversive, queer, and performative aspects of Big Gay Church position it as a collaborative experience of artivism, where by merely attending with an open spirit, art educators are participating in a creative intervention for activist aims; we want people to rethink the predominantly negative relationships and interactions between conservative Christianity and queers (see Figs. 15-17). 
The First Baftimore United Congregation of Wonder, Hope, + Light

invites you to

\section{Big Gay Church}

Sunday Morning Services @ 9:00 a.m.

Room 328/329, Baltimore Convention Center

*Please bring an open mind, heart, and sense of humor.

Fig. 15 Invitation to the First Annual Big Gay Church in Baltimore

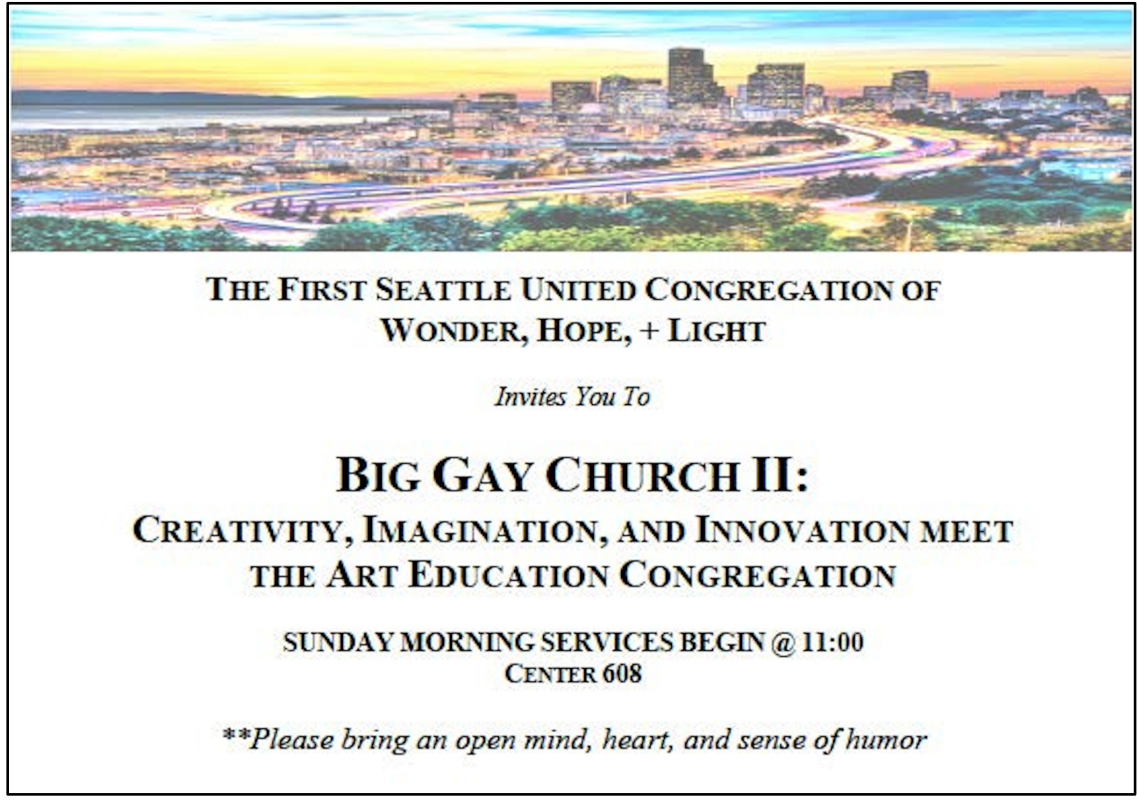

Fig. 16 Invitation to the Second Annual Big Gay Church in Seattle

Finding Big Gay Church: An Academic Congregation Exploring LGBTQ Intersections with Religion, Art, 


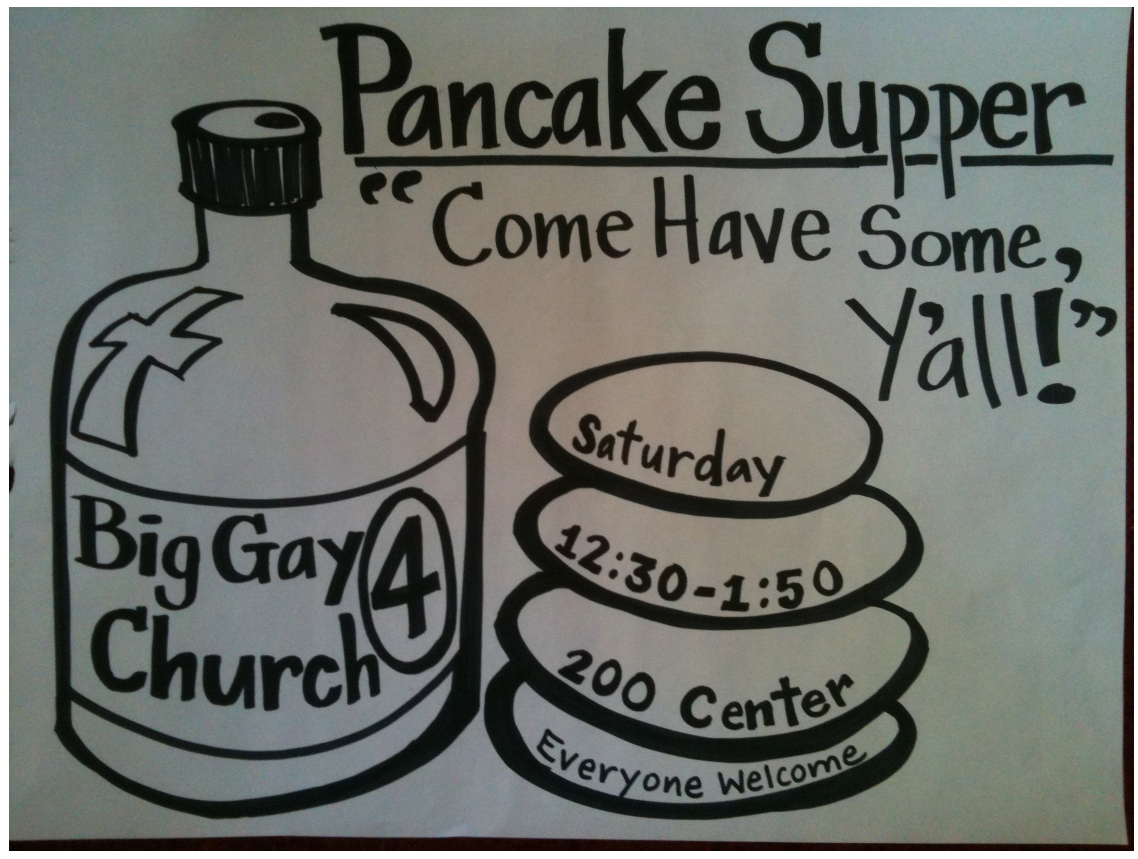

Fig. 17 Invitation to the Fourth Annual Big Gay Church in Fort Worth

Simple creative collaborations, such as making colorful paper hats and angel wings and banners for the impromptu Pride parade, sharing homemade jams, and kazoo-filled processionals, foster fellowship through interaction, communication, and collaboration, (see Fig. 18). Displaying these artifacts in public conference spaces afterwards is a signal and record of our presence. Where many churches make efforts to condemn, exclude, or "repair" queer folks, we find ways to reimagine Big Gay Church as a place that recognizes the power of diverse sexualities and gender identities, among multiple other differences. 


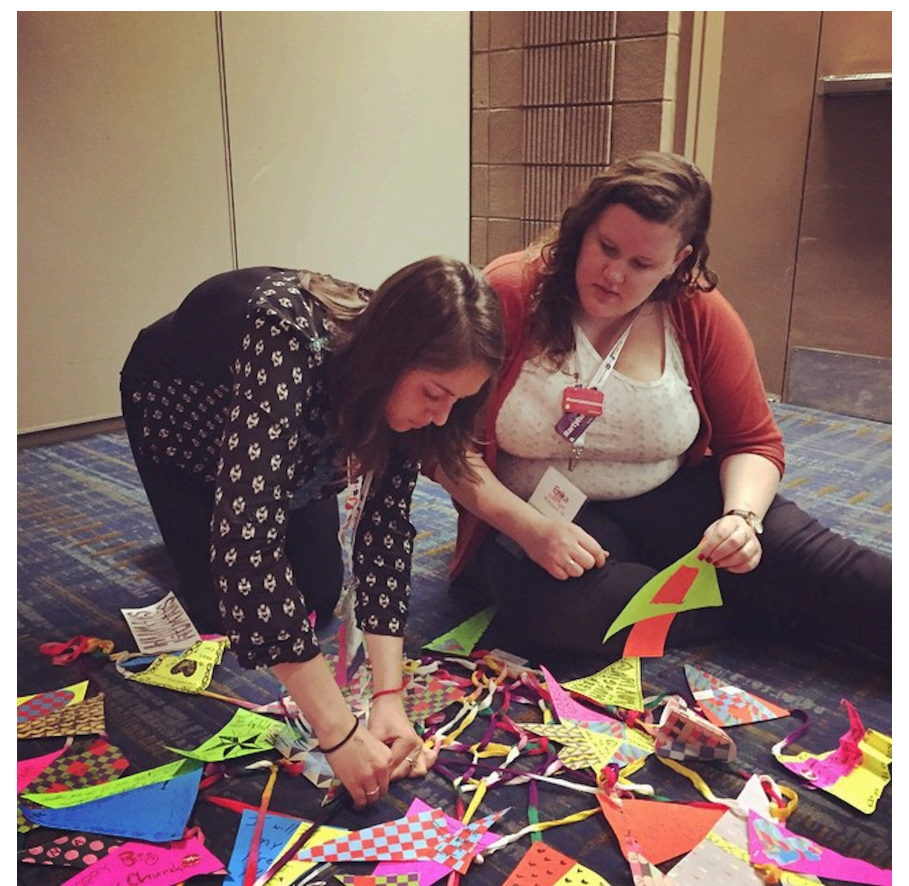

Fig. 18 Big Gay Church attendees making banners for parade and display

In Big Gay Church, we do this in multiple ways. Sister Sanders' slideshow lectures provide documentation and critical consideration of the contributions of queer artists to religion and culture and of religion on queer artists, arts, and culture. In early years, Sister Sanders acknowledged classic queer masters of religious (and homoerotic) art including Michelangelo, Da Vinci, and Caravaggio up through more modern artists like Andy Warhol. Sister Sanders also provided an in-depth exploration of the Catholic League's ability to bully the U.S. National Portrait Gallery into censoring the exhibition "Hide/Seek: Difference and Desire in American Portraiture," the first to "examine homosexual identity in 19th and 20thcentury American art" under the imprimatur and blessing of the Smithsonian Institution (Knight). The Catholic League specifically objected to David Wojnarowicz's video condemning the lack of institutional and governmental responses in the early years of the AIDS crisis, ostensibly because it uses the crucifix covered in ants as a symbol for Christian apathy (Knight).

Knight argues that the successful censorship campaign is simply anti-gay bullying under the guise of religious doctrine. Sister Sanders was able to augment an academic lecture based on extensive research with personal anecdotes and observations from attending the exhibit. Parishioners leave with a more informed perspective of the current intersections and tensions between queerness, dominant cultural discourses, the contemporary art world, and the influence of conservative religious dogma.

Another way we consistently foreground queerness in Big Gay Church is through troupe members performing gender and sexuality as more fluid and queer than fixed and binary. Miss Jeanette has appeared alternatively in a suit

Finding Big Gay Church: An Academic Congregation Exploring LGBTQ Intersections with Religion, Art, 
and tie to tell personal stories about gender, sexuality, and an evangelical Christian upbringing. Sister Sanders is a campy drag persona; Hermana Harry a more ghostly and ephemeral being. Brother Love presents as visibly female. The Reverend and Deacon exist in an ambiguous gender space, professionally and performatively. Nothing fits traditional expectations in any neat and tidy ways. Collectively, we recognize and value those possibilities and multiplicities in ourselves and in one another, honoring the vitality these differences, and this fluidity, can bring. As some churches continue to make efforts to condemn, exclude, or "repair" queer folks, we strive to find ways to turn Big Gay Church into a place that recognizes and celebrates diverse sexualities and gender identities. Since these conservative religious discourses also impact public policy and the civil rights of queer people, we must find ways to use our pulpit to move queer people and allies to interrupt the status quo and work toward a more just world outside the walls of a convention center.

\section{Big Gay Church and performance pedagogy/studies}

Once [gays] attain key positions, they will seek to remove all stigma against homosexuality and seek to redefine, reeducate (deceive) and reshape society to accept their depravity. (Lee)

Big Gay Church is both performance and pedagogy. During services, we become what McLaren calls the "researcher-as-performer," engaging fully in the political, kinetic, destructive, and transcendental aspects of presenting/ performing/creating. Our Right Reverend is really a reverend, our "nun" is our sister, Miss Jeanette is teaching us moral lessons and providing us with shining LGBTQ angels and saints to watch over and lead us.

We interrupt the regularly scheduled program, using performance and its liminal spaces for encountering culture, politics, and education (Garoain and Gaudelius). We are queering and re-purposing the academy as a vital site for resistance and autonomy, a place for collective participatory action by critical citizens acting in concert. Through the performative, we hope to facilitate connections that participants make between the personal and the pedagogical (Giroux). What can we learn from ourselves?

We have some evidence this is happening. Comments submitted by one of our Big Gay Church parishioners explains:

Big Gay Church is a rare instance of genuine community in our home discipline of art education. In attending these sessions ... OK! Services . . . We are no longer colleagues. We are people who come together to speak, listen, learn and commune with one another toward a higher 
cause. We are there to remind ourselves of the true meaning of social justice, of care and belonging as bell hooks defines it, which is palpable in the narratives that suffuse the air. I feel relieved and relaxed in the "pews" of Big Gay Church. When my eyes meet those of other "parishioners," I sense what it means to be a part of a genuine community pushing for something bigger and better than ourselves. (Cate, parishioner)

Embracing critical performance pedagogies as research, teaching, and learning paradigms emphasizes their potential educational, political, cultural, and societal benefits (Denzin "Critical Performance"). For Conquergood, "[p]erformance is a way of knowing, a way of showing, a way of interpreting and a method for building shared understanding. Performance is immediate, partial, always incomplete and always processual" (qtd. in Denzin "Critical Performance" 29). Big Gay Church is not a place, it is a collective and co-constructed experience and fellowship that happens in the present - in the immediate moment, during an annual conference. But it does not end there. It extends beyond that moment. People continue to process their experience(s), sometimes using our offerings, the trading cards or other talismans from Big Gay Church services, as touchstones for personal remembering and reflecting.

For us as the leaders, Big Gay Church requires rigorous individual and collaborative research and preparation for the academic portions of each service and to contextualize and theorize this work. It also requires us, as presenters/ performers, to model "a communitarian dialogical ethic of care and responsibility" where everyone treats "persons and their cares and concerns with dignity and respect" (Denzin "Politics" 133). We invite people to share their own stories and concerns, to seek and offer support, much as we share our stories and concerns and support one another throughout the year. We provide possibilities for connection.

We also deliberately use performance-based pedagogies to construct what Denzin calls a "civic, participatory and collaborative project" where "members of the community, as cultural workers and co-performers in theatres of resistance, create empowering performance texts and performance events" ("Critical Performance" 263). We want Big Gay Church to be an example of a "radical democratic pedagogy [that] requires [people] committed to taking risks; persons willing to act in situations where the outcome cannot be predicted in advance" and who recognize that "in these pedagogical spaces there are not leaders and followers; there are only co-participants, persons jointly working together to develop new lines of action, new stories, new narratives in a collaborative effort" (Bishop 207). Again, feedback from parishioners provides some assurances this is happening:

Big Gay Church is about encountering, exploring, and celebrating the vast spectrum of subjectivities that comprise our human species. It's so important to have spaces in this world where people can encounter

Finding Big Gay Church: An Academic Congregation Exploring LGBTQ Intersections with Religion, Art, 
complexity - especially those differences, complexities, and contradictions that make up any one person. Big Gay Church is about showing up and being present in the world, in all its splendor and heartbreak. Big Gay Church is where you witness the fragility and strength of people and learn that art education can be so much more than we currently imagine/experience it to be. I go to Big Gay Church to be inspired, energized, and fortified by love and acceptance. (Violet, parishioner)

According to Conquergood ("Moral Act") such critical, risk-taking citizenscholars must also possess the "energy, imagination, courage, and commitment to create" new, more liberating texts and discourses (10). Big Gay Church takes risks by inviting the personal and emotional and relational into a place primarily designated as rational, academic, and reserved. Critical performance pedagogies require criticism and action. We are modeling this. We are enacting this intervention; we are writing and publishing about it. Our congregation members are experiencing our scholarship directly, not reading about it. We offer a more loving approach to creating these new discourses. A regular Big Gay Church congregant remarks:

What sticks with me is the love fest it feels like, and such kinds of occurrences feel few and far between at conferences so I am most grateful for [Big Gay Church]. Although you make a direct plea/action call for social change through creating a new church construct, the feeling at the meetings is joyful and celebratory, liberating. (Kiki, parishioner)

Big Gay Church, following Denzin's advice, uses performative pedagogies to embrace queer studies, transforming a traditional academic conference session into a "sacred aesthetic place" and time ("Politics" 133). It provides "a way of acting on the world in order to change it" (Denzin "Critical Performance" 267). Big Gay Church is a site of intervention, struggle, and "transgressive achievement" (Conquergood "Beyond the Text" 32). It is a "concrete situation ... being transformed through acts of resistance" (Denzin "Politics" 135). This resistance occurs simultaneously in multiple ways (as in Brechtian theatre):

The performance becomes the vehicle for moving persons, subjects, performers and audience members, into new, critical, political spaces. The performance gives the audience, and the performers, "equipment for [this] journey: empathy and intellect, passion and critique." (Denzin "Critical Performance" 265)

The relative absence of spaces and times for these kinds of experiences in professional academic settings is profound. Accordingly, providing one has led to 
profound outcomes for a conference session, too. A classroom art teacher and annual Big Gay Church attendee confesses:

I feel confident in saying [the Seattle service] was life changing for me. [The] sermon on Forgiveness really hit home...I wasn't expecting to be touched so deeply, but [the] sermon and the "FORGIVEN" cards [the Reverend] passed out made me think about my life and how selfempowering it is to forgive. I have kept one in my wallet and one on the fridge since that day to constantly remind myself (although not easy) to FORGIVE. (Tasha, parishioner)

Big Gay Church exists in a hyperactive, open-ended intersection of performance as imagination and action. As performers, we embody characters who traditionally experience exclusion and punishment as queer people with regards to conservative religions. In our performance, we not only imagine what it might be like if these stereotypes were false, but we become these characters rendering, albeit temporarily, an embodied re-vision. The audience becomes a supportive congregation, co-participatory members in a collaborative performance (Denzin "Politics"). We reclaim concepts like church, family, love, and Christianity from hate-based religious doctrines and practices. Where "the performative and the political intersect on the terrain of a praxis-based ethic," we use performance pedagogy to "embody love, hope, care, and compassion," portraying a more progressive possibility, attempting to use Big Gay Church "to change the world" (Denzin "Politics" 129) by starting in the field we already inhabit. A regularly attending member of the congregation suggests we are already doing this:

The performative nature of Big Gay Church means that content and form of the service will interact to spark new ways of thinking about the issues. And, after a service, l've experienced thought-provoking dialogues and realizations that linger long after the conference. Big Gay Church is socially engaged arts practice at its finest. (Violet, parishioner)

We want this conference session to be meaningful in terms of its content, its emotional impact, and its use of the arts to deliver both.

\section{We are the change}

Big Gay Church stakes a territory within the academy, in art education, in our national organization and annual conference, and now in the scholarly record. We have laid a counter-claim to church and religion, challenging its overwhelming negative history with respect to queer people, forming our own 
flock. We seek to critically confront conservative Christian church doctrines, their positioning and treatment of LGBTQ people, and the overwhelming influence their beliefs have on cultural beliefs, acceptable behavior, and public policy. We force a confrontation between our learned beliefs and identities, our occupations and our culture. We confront tough questions, asking: How has church shaped us? How can we (re)shape it? How does/can recognizing, accepting, and supporting queer people, culture, values, presence, and contributions to the church change church? Change queer people? Change our political, educational, and sociocultural climate? We interrogate the ways conservative Christian churches and queer people impact each other and aim to explore analyses and possible revisions to these relationships. We have the power to redraw the boundaries, make contact, build bridges, connect. Big Gay Church shows there are ways to hold such seeming contradictions in tension, to forgo resolution for exploration, rejection for consideration of possibilities, of what was and what might be.

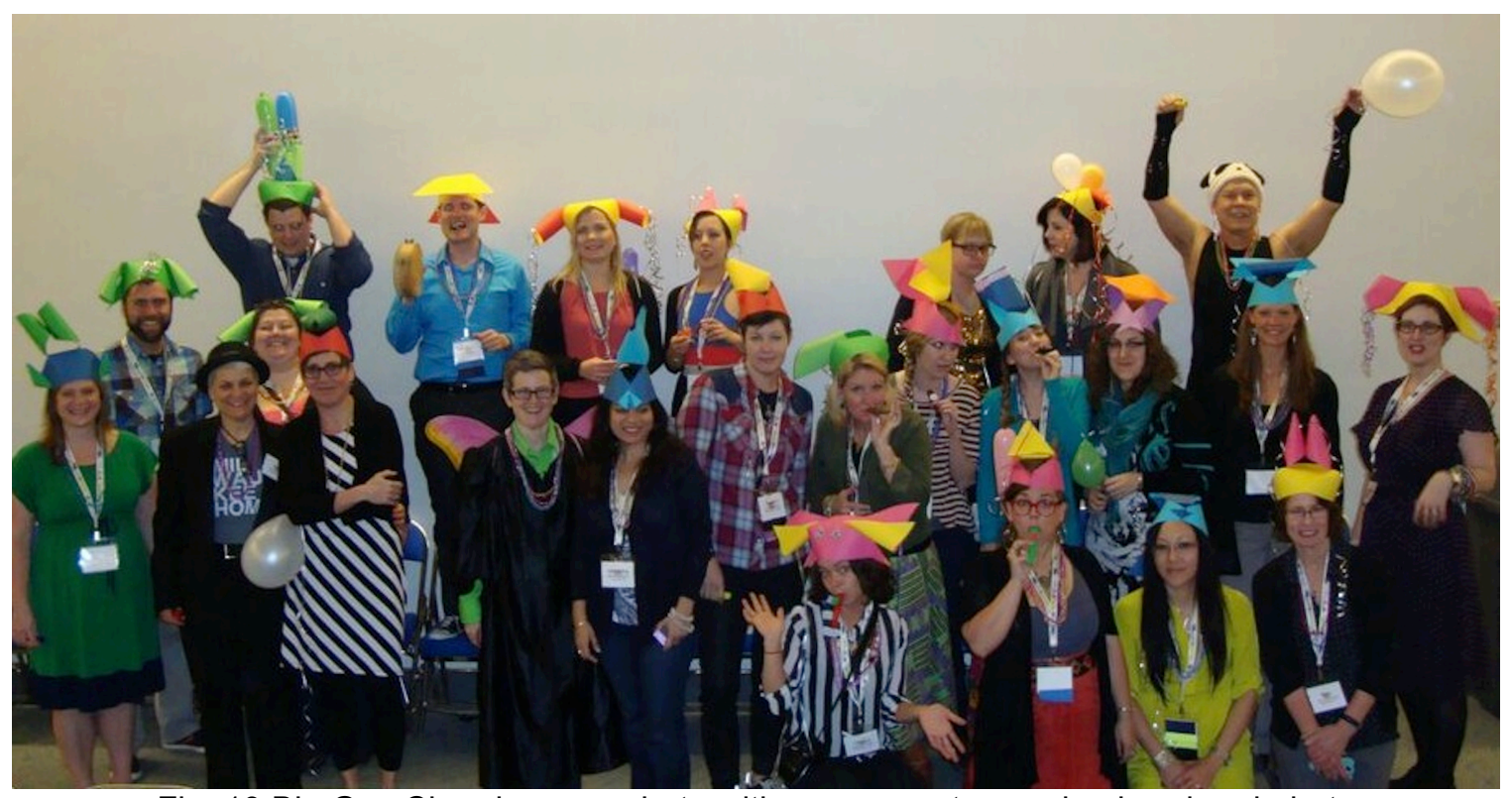

Fig. 19 Big Gay Church group photo with congregants wearing handmade hats 


\section{References}

8: The Mormon Proposition. Writer/Director/Producer Reed Cowan. Los Angeles, California: Red Flag Releasing, 2010. Film.

Barton, Bernadette C."Abomination—Life as a Bible Belt Gay." Journal of Homosexuality 57.4 (2010): 465-484. Print.

Bishop, Russell. "Freeing ourselves from neo-colonial domination in research: A Maori approach to creating knowledge." International Journal of Qualitative Studies in Education II (1998): 199-219. Print.

Brooke, H. L. "Gays, Ex-gays, and Ex-ex-gays: Examining Key Religious, Ethical, and Diversity Issues: A Follow-up Interview with Douglas Haldeman, Ariel Shidlo, Warren Throckmorton, and Mark Yarhouse."Journal of Psychology and Christianity 24.4 (2005): 343-351. Print.

Buchanan, Melinda, Kristina Dzelme, Dale Harris, and Lorna Hecker. "Challenges of Being Simultaneously Gay or Lesbian and Spiritual and/or Religious: A Narrative Perspective." The American Journal of Family Therapy 29.5 (2001): 435-449.

Callaghan, Tonya D. "David versus Goliath: Addressing Contradictory Catholic Doctrine Head On." Journal of LGBT Youth 7.1 (2010): 85-90. Print.

Candreva, Thomas D. "A New Impediment: The Vatican's Document Regulating Admission to Seminaries and Ordination Revives an Almost Extinct Legal Device." America 27 February 2006: 20-22. Print.

Cianciatto, Jason and Sean Cahill. Youth Caught in the Crosshairs: The Third Wave of Ex-gay Activism. New York, NY: National Gay and Lesbian Task Force Policy Institute, 2006. Print.

Conquergood, Dwight. "Beyond the Text: Toward a Performative Cultural Politics." The Future of Performance Studies: Visions and Revisions. Ed. Sheron J. Dailey. Annandale, VA: National Communication Association. 1998. 25-36. Print.

---. "Performing as a Moral Act: Ethical Dimensions of the Ethnography of Performance." Literature in Performance 5.1 (1985): 1-13. Print.

Dennis, Jeffery P. "Lying with Man as with Woman: Rethinking the Impact of Religious Discourse on Gay Community Strength." Journal of Homosexuality 44.1 (2003): 43-60. Print. 
Denzin, Norman K. "The Politics and Ethic of Performance Pedagogy: Toward a Pedagogy of Hope." Critical Pedagogy: Where Are We Now? Eds. Peter McLaren and Joe Kincheloe. New York: Peter Lang Publishing. 2007. 127143. Print.

---. "A Critical Performance Pedagogy that Matters." Ethnography and Education 4.3 (2009): 255-270.

Donadio, Rachel. "On Gay Priests, Pope Asks, 'Who Am I to Judge?" New York Times 30 July 2013 New York edition: A1. Print.

Foucault, Michel. The History of Sexuality, Volume I: An Introduction. New York: Random House, 1980. Print.

Ganzevoort, R. Ruard, Mark van der Laan, and Erik Olsman. Growing Up Gay and Religious: Conflict, Dialogue, and Religious Identity Strategies. Mental Health, Religion \& Culture 14.3 (2011): 209-222. Print.

Garoian, Charles R., and Yvonne M. Gaudelius. Spectacle Pedagogy: Art, Politics and Visual Culture. Albany: State University of New York, 2008. Print.

Ginwright, Shawn, and Julio Cammarota. "Youth Activism in the Urban Community: Learning Critical Civic Praxis within Community Organizations." International Journal of Qualitative Studies in Education 20.6 (2007): 693-710. Print.

Ginwright, Shawn, Julio Cammarota, J., and Pedro Noguera. "Youth, Social Justice and Communities: Toward a Theory of Urban Change. "Social Justice 32.3 (2005): 24-40. Print.

Giroux, Henry. Impure Acts: The Practical Politics of Cultural Studies. New York: Routledge, 2000. Print.

King, Jr., Reverend Dr. Martin Luther. "The Birth of a New Age." Alpha Phi Alpha Fraternity, Buffalo, New York. 11 August 1956. Web.

---. "Letter from Birmingham Jail." African Studies Center. University of Pennsylvania, Philadelphia, Pennsylvania. 1963, para. 24. Web. 4 Feb. 2016.

Knight, Christopher. "Is the Censored David Wojnarowicz Video Really 'AntiChristian'?" Los Angeles Times, 2 Dec. 2010. Web. 14 Dec. 2015. 
Lee, Robert T. "Against Homosexuality." Online quotations. Society for the Practical Establishment and Perpetuation of the Ten Commandments. Tencommandments.org, 20 Jan. 2011. Web. 5 Feb. 2016.

LeVay, Simon, and Elisabeth Nonas. City of Friends: A Portrait of the Gay and Lesbian Community in America. Cambridge, MA: MIT Press, 1995. Print.

Lynch, John. "Institution and Imprimatur: Institutional Rhetoric and the Failure of the Catholic Church's Pastoral Letter on Homosexuality." Rhetoric \& Public Affairs 8.3 (2005): 383-404. Print.

McLaren, Peter. Schooling as a Ritual Performance: Toward a Political Economy of Educational Symbols and Gestures ( $3^{\text {rd }}$ ed.). Lanham, MD: Rowman \& Littlefield, 1999. Print.

Menken, Henry Louis. (1927). H. L. Mencken letter to Charles Green Shaw, 1927 Dec. 2. Charles Green Shaw papers, 1686, 1833-1979, bulk, 1909-1974. Archives of American Art, Smithsonian Institution. 10 February 2016. Web.

Press, Bill. "Press: The Sad Legacy of Jerry Falwell." Milford Daily News (Massachusetts) 18 May 2007. 15 February 2015. Print.

Rhoades, Mindi. LGBTQ youth + video artivism. Studies in Art Education 53.4 (2012): 317-329. Print.

---. "iDo." National Art Education Association Conference. New York, NY. 4 May 2012. Conference presentation.

Sanders III, James. "Breathing Curiously: Queering the Curriculum Body." Curriculum and the Cultural Body. Ed. S. Springgay and D. Freedman. New York: Lange, 2007. 217-234. Print.

Sandoval, Chela, and Guisela Latorre. "Chicana/o Artivism: Judy Baca's Digital Work with Youth of Color." The John D. and Catherine T. MacArthur Foundation Series on Digital Media and Learning, Learning, Race, and Ethnicity: Youth and Digital Media. Ed. A. Everett. Cambridge, MA: The MIT Press, 2008. 81-108. Print.

Schuck, Kathrin, and Becky Liddle. "Religious Conflicts Experienced by Lesbian, Gay, and Bisexual Individuals." Journal of Gay \& Lesbian Psychotherapy 5.2 (2001): 63 - 82. Print.

Schwartz, Joseph. "Investigating Differences in Public Support for Gay Rights Issues. Journal of Homosexuality 57.6 (2010): 748-759. Print.

Finding Big Gay Church: An Academic Congregation Exploring LGBTQ Intersections with Religion, Art, 
Sharlet, Jeff. The family: The secret fundamentalism at the heart of American power. New York: HarperCollins, 2009. Print.

Sisters of Perpetual Indulgence. "The Sisters of Perpetual Indulgence." Youtube, YouTube, 31 Mar. 2009. Web. 4 Feb. 2016.

Staines, Bill. "A place in the choir." Whistle of the Jay. Mineral River Music, BMI. 1979. Song.

The Holy Bible, New International Version. Grand Rapids: Zondervan House, 1984. Print.

Williams, Alex. "Gay Teenager Stirs a Storm." The New York Times 17 July 2005. 10 February 2016. Web.

Wolff, Joshua and Heather Himes. "Purposeful Exclusion of Sexual Minority Youth in Christian Higher Education: The Implications of Discrimination." Christian Higher Education 9.5 (2010): 439-460. Print.

Zacko-Smith, Jeffrey D. and G. Pritchy Smith. "Recognizing and Utilizing Queer Pedagogy." Multicultural Education Fall (2010): 2-9. Print. 